\title{
Insulin Sensitivity of Protein and Glucose Metabolism in Human Forearm Skeletal Muscle
}

\author{
R. J. Louard, D. A. Fryburg, * R. A. Gelfand, ${ }^{*}$ and E. J. Barrett* \\ Department of Internal Medicine, Endocrinology Section, Yale University School of Medicine, New Haven, Connecticut 06510; \\ *Department of Medicine, Endocrinology Section, University of Virginia Health Sciences Center, Charlottesville, Virginia 22903; \\ and ${ }^{\ddagger}$ Department of Clinical Research, Pfizer Central Research, Groton, Connecticut 06340
}

\begin{abstract}
Physiologic increases of insulin promote net amino acid uptake and protein anabolism in forearm skeletal muscle by restraining protein degradation. The sensitivity of this process to insulin is not known. Using the forearm perfusion method, we infused insulin locally in the brachial artery at rates of 0.00 ( saline control), 0.01, 0.02, 0.035, or $0.05 \mathrm{mU} / \mathrm{min}$ per $\mathrm{kg}$ for 150 min to increase local forearm plasma insulin concentration by $0, \sim 20, \sim 35, \sim 60$, and $\sim 120 \mu \mathrm{U} / \mathrm{ml}(n=35)$. L-[ring-2,6$\left.{ }^{3} \mathrm{H}\right]$ phenylalanine and $\mathrm{L}-\left[1-{ }^{14} \mathrm{C}\right]$ leucine were infused systemically, and the net forearm balance, rate of appearance $\left(\boldsymbol{R}_{\mathrm{a}}\right)$ and rate of disposal $\left(\boldsymbol{R}_{\mathrm{d}}\right)$ of phenylalanine and leucine, and forearm glucose balance were measured basally and in response to insulin infusion. Compared to saline, increasing rates of insulin infusion progressively increased net forearm glucose uptake from $0.9 \mu \mathrm{mol} / \mathrm{min}$ per $100 \mathrm{ml}$ (saline) to $1.0,1.8,2.4$, and 4.7 $\mu \mathrm{mol} / \mathrm{min}$ per $100 \mathrm{ml}$ forearm, respectively. Net forearm balance for phenylalanine and leucine was significantly less negative than basal $(P<0.01$ for each) in response to the lowest dose insulin infusion, $0.01 \mathrm{mU} / \mathrm{min}$ per $\mathrm{kg}$, and all higher rates of insulin infusion. Phenylalanine and leucine $\boldsymbol{R}_{\mathrm{a}}$ declined by $\sim 38$ and $40 \%$ with the lowest dose insulin infusion. Higher doses of insulin produced no greater effect (decline in $\boldsymbol{R}_{\mathrm{a}}$ varied between 26 and $42 \%$ for phenylalanine and $30-50 \%$ for leucine). In contrast, $\boldsymbol{R}_{\mathrm{d}}$ for phenylalanine and leucine did not change with insulin.

We conclude that even modest increases of plasma insulin can markedly suppress proteolysis, measured by phenylalanine $\boldsymbol{R}_{\mathrm{a}}$, in human forearm skeletal muscle. Further increments of insulin within the physiologic range augment glucose uptake but have little additional effect on phenylalanine $\boldsymbol{R}_{\mathrm{a}}$ or balance. These results suggest that proteolysis in human skeletal muscle is more sensitive than glucose uptake to physiologic increments in insulin. (J. Clin. Invest. 1992. 90:2348-2354.) Key words: phenylalanine $\bullet$ leucine $\bullet$ proteolysis $\bullet$ forearm balance $\bullet$ amino acid tracer kinetics
\end{abstract}

Address correspondence to Dr. R. J. Louard, Department of Internal Medicine, Endocrinology Section, Yale University School of Medicine, P. O. Box 3333, New Haven, CT 06510.

Received for publication 2 December 1991 and in revised form 26 May 1992.

\section{J. Clin. Invest.}

(c) The American Society for Clinical Investigation, Inc. $0021-9738 / 92 / 12 / 2348 / 07 \quad \$ 2.00$

Volume 90, December 1992, 2348-2354

\section{Introduction}

Insulin plays a major role in the regulation of protein, fat, and carbohydrate metabolism (1). In humans, increasing the systemic concentration of insulin produces dose-dependent effects on whole body amino acid (2), fatty acid (3) and glucose metabolism (3-5). Reductions of amino acid concentrations in plasma in response to hyperinsulinemia are attributed to suppression of their rates of appearance $\left(R_{\mathrm{a}}\right)$, which should reflect whole body protein degradation $(6)$. Though providing important information about the sensitivity of whole body protein stores to the antiproteolytic action of insulin, studies using systemic insulin infusion and whole body tracer methods do not address insulin's effects on specific tissues. Moreover, systemic insulin infusion is associated with multiple hormonal and substrate changes, not the least of which is a pronounced hypoaminoacidemia $(2)$. These changes, particularly altered amino acid availability $(7,8)$, can alter the apparent response of body protein metabolism to hyperinsulinemia and complicate the interpretation of tracer studies of whole body protein turnover.

The effects of hyperinsulinemia on skeletal muscle, the largest pool of protein in the body, has been of particular interest. Pozefsky et al. (9), using the forearm perfusion technique, observed that local hyperinsulinemia diminished net forearm amino acid release and stimulated glucose uptake. With direct infusion of insulin into the brachial artery, the effects of hyperinsulinemia on forearm skeletal muscle metabolism can be examined directly (9-13) without the confounding influence of altered substrate concentrations that accompany systemic insulin administration $(14,15)$. Using the forearm perfusion technique together with amino acid tracers, we have previously shown that increases of plasma insulin to high physiologic levels locally within the forearm promotes net skeletal muscle amino acid uptake and net protein anabolism by inhibiting proteolysis. Protein synthesis in muscle was not affected and systemic insulinemia and aminoacidemia were unchanged (10). In the current study we extend these observations to cover the range of insulin concentrations encountered physiologically. Our findings demonstrate that this dose-response relationship differs markedly from that of insulin action on forearm glucose disposal.

\section{Methods}

Subjects. Overall, 39 adult volunteers ( $26 \mathrm{M}, 13 \mathrm{~F}$ ) were studied. All subjects were within $15 \%$ of their ideal body weight (Metropolitan Life

1. Abbreviations used in this paper: [A], arterial concentration; $\mathrm{F}$, forearm blood flow; $R_{a}$, rate of appearance; $R_{d}$, rate of disposal; [V], venous concentration. 
Insurance tables, 1983). None had a history of endocrine or other major organ system disease, none were taking any medication. The purpose and potential risks of the study were explained to all subjects and informed, written consent was obtained from each before participation. The study protocol was reviewed and approved by the Human Investigation Committee of the Yale University School of Medicine.

Experimental design. All subjects were studied in the postabsorptive state after an overnight fast. Catheters were introduced into a brachial artery and retrograde into an ipsilateral deep forearm vein. The patency of the catheters was maintained by a slow infusion of normal saline. All subjects received a 5-h primed, continuous infusion of $\mathrm{L}-$ [ring-2,6,- ${ }^{3} \mathrm{H}$ ]phenylalanine $(\sim 32 \mu \mathrm{Ci}, 0.52 \mu \mathrm{Ci} / \mathrm{min})$ and $\mathrm{L}-[1-$ ${ }^{14} \mathrm{C}$ leucine $(\sim 8 \mu \mathrm{Ci}, 0.13 \mu \mathrm{Ci} / \mathrm{min})$ via an antecubital vein in the contralateral arm. After a 150 -min tracer equilibration period, insulin (diluted in a solution of normal saline and albumin) was infused for 150 min directly into the brachial artery at the following rates (in $\mathrm{mU} /$ $\mathrm{kg} / \mathrm{min}$ ): 0.00 (saline controls) $(n=10), 0.01(n=7), 0.02(n=7)$, and $0.035(n=8)$. The design for the $0.05 \mathrm{mU} / \mathrm{kg} / \mathrm{min}$ infused group $(n=7)$ was a 4-h infusion (120-min basal period and 120-min insulin period). The data obtained from this group were previously published (10).

Paired arterial and deep venous blood samples were obtained at 15-min intervals during the last hour of both the basal and the insulininfusion period, by which time all measurements displayed steady state conditions. For 2 min before and during withdrawal of each deep venous blood sample, a pediatric sphyngomanometer cuff was inflated about the wrist to $200 \mathrm{mmHg}$ to exclude blood flow to the hand. Forearm plasma flow was measured immediately after each arterio-venous sampling interval by dilution of indocyanine green dye (Hynson, Westcott, and Dunning Products, Baltimore, MD) infused intraarterially for $5 \mathrm{~min}$ with the wrist cuff inflated. Blood flow was derived by dividing plasma flow by (1-hematocrit). Forearm volume was measured by water displacement.

Calculations. The net forearm balances and forearm amino acid kinetics were calculated as previously described $(10,16)$. Briefly, the net forearm balance for a given substrate can be calculated using the
Fick principle by knowing the arterial [A] and venous [V] concentration of the substrate and the forearm blood flow $(F)$ :

Net balance $=([\mathrm{A}]-[\mathrm{V}]) \times \mathrm{F}$

For a given amino acid, the net balance reflects the contribution of two simultaneous processes: the net uptake or rate of disposal $\left(R_{\mathrm{d}}\right)$ of arterial substrate and the net release or rate of appearance $\left(R_{\mathrm{a}}\right)$. That is:

Net balance $=R_{\mathrm{d}}-R_{\mathrm{a}}$

For phenylalanine and leucine, tissue disposal can be calculated from the measured fractional extraction $(E)$ of tracer:

$R_{\mathrm{d}}=\mathrm{E} \times[\mathrm{A}] \times \mathrm{F}$

where $\mathrm{E}$ is the arterio-venous difference in tracer radioactivity divided by the arterial tracer radioactivity concentration (all in disintegrations per minute per milliliter). The release of phenylalanine or leucine can be calculated using as the difference of the net balance and $R_{\mathrm{d}}$ :

$R_{\mathrm{a}}=(\mathrm{E} \times[\mathrm{A}] \times \mathrm{F})-(([\mathrm{A}]-[\mathrm{V}]) \times \mathrm{F})$

which reduces to the expression:

$R_{\mathrm{a}}=\mathrm{F} \times[\mathrm{V}] \times(1-\mathrm{SAv} / \mathrm{SAa})$

where SAa and SAv denote the specific activity $(\mathrm{dpm} / \mathrm{nmol})$ of the amino acid in artery and vein, respectively.

The above calculations define the kinetics of amino acid exchange between forearm muscle and circulating blood. For phenylalanine, which is neither synthesized nor metabolized in muscle (17), the measured rate of disappearance of tracer across the forearm should reflect its rate of incorporation into protein, while tissue release of new, unlabeled phenylalanine should reflect its release from the breakdown of tissue protein. For leucine, $R_{\mathrm{d}}$ represents the total disposal of leucine entering tissue via the artery, but it does not distinguish between its possible fates in muscle, namely, incorporation into protein, transamination, or complete oxidation to $\mathrm{CO}_{2}$.

Analytical methods. Blood glucose concentration was measured by

Table I. Arterial Substrate and Insulin Concentrations

\begin{tabular}{|c|c|c|c|c|c|}
\hline & \multicolumn{5}{|c|}{ Insulin infusion rate (mU/kg per $\mathrm{min}$ ) } \\
\hline & 0.00 & 0.01 & 0.02 & 0.035 & $0.05^{*}$ \\
\hline \multicolumn{6}{|c|}{ Deep vein insulin $(\mu U / m l)$} \\
\hline Basal & $7 \pm 1$ & $9 \pm 2$ & $4 \pm 1$ & $5 \pm 1$ & $6 \pm 1$ \\
\hline Infused & $6 \pm 1$ & $33 \pm 4^{\ddagger}$ & $40 \pm 5^{\ddagger}$ & $67 \pm 8^{\S}$ & $124 \pm 11^{\ddagger}$ \\
\hline \multicolumn{6}{|c|}{ Arterial glucose $(m M)$} \\
\hline Basal & $4.4 \pm 0.1$ & $4.0 \pm 0.2$ & $4.4 \pm 0.1$ & $4.6 \pm 0.1$ & $4.6 \pm 0.1$ \\
\hline Infused & $4.3 \pm 0.1^{\ddagger}$ & $3.8 \pm 0.2^{\S}$ & $4.4 \pm 0.2$ & $4.3 \pm 0.1^{\S}$ & $4.3 \pm 0.1^{\S}$ \\
\hline \multicolumn{6}{|c|}{ Arterial phenylalanine $(\mathrm{nmol} / \mathrm{ml})$} \\
\hline Basal & $45 \pm 2$ & $42 \pm 2$ & $48 \pm 3$ & $44 \pm 2$ & $48 \pm 1$ \\
\hline Infused & $44 \pm 2$ & $40 \pm 2$ & $46 \pm 3$ & $44 \pm 2$ & $49 \pm 1$ \\
\hline \multicolumn{6}{|c|}{ Arterial leucine $(\mathrm{nmol} / \mathrm{ml})$} \\
\hline Basal & $114 \pm 4$ & $116 \pm 8$ & $100 \pm 2$ & $105 \pm 7$ & $110 \pm 3$ \\
\hline Infused & $113 \pm 5$ & $112 \pm 6$ & $106 \pm 3^{\S}$ & $105 \pm 7$ & $108 \pm 2$ \\
\hline \multicolumn{6}{|c|}{$\begin{array}{l}\text { Blood flow }(\mathrm{ml} / \mathrm{min} \text { per } 100 \mathrm{ml} \\
\text { forearm vol })\end{array}$} \\
\hline Basal & $3.6 \pm 0.4$ & $4.2 \pm 0.6$ & $4.1 \pm 0.7$ & $5.2 \pm 0.6$ & $3.2 \pm 0.2$ \\
\hline Infused & $3.4 \pm 0.3$ & $4.6 \pm 0.8$ & $3.8 \pm 0.4$ & $5.8 \pm 0.8$ & $4.0 \pm 0.4^{\S}$ \\
\hline \multicolumn{6}{|c|}{ Systemic insulin $(\mu U / m l)^{\|}$} \\
\hline & - & $10 \pm 2$ & $4 \pm 2$ & $5 \pm 1$ & $6 \pm 1$ \\
\hline
\end{tabular}

${ }^{*}$ See reference $10 .{ }^{\ddagger} P<0.01$ basal vs. insulin-infused period. ${ }^{\S} P<0.05$ basal vs. insulin-infused period. "Systemic insulin concentrations were obtained from the contralateral arm at the end of the insulin infusion period. 


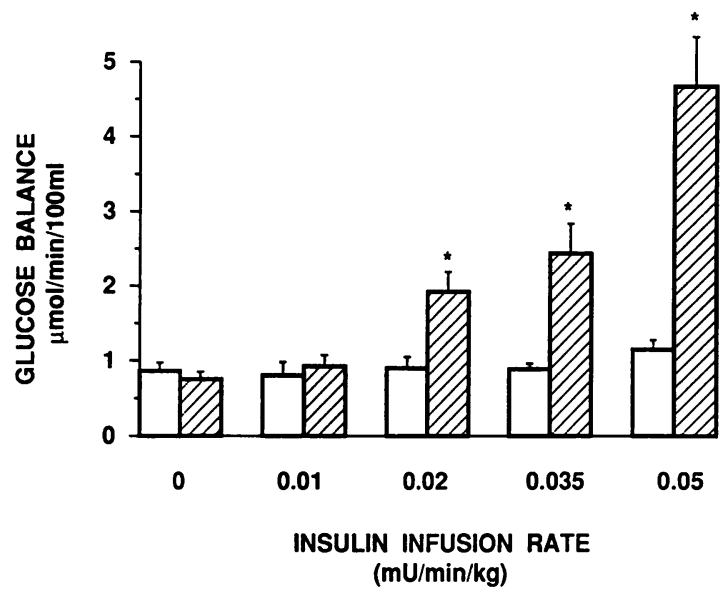

Figure 1. Effect of insulin on forearm skeletal muscle glucose uptake. Values are means \pm SEM during the last hour of the basal period (open bars) and insulin infused period ( hatched bars). *Statistically significant differences $(P<0.01)$ between basal and insulin-infused periods.

the glucose oxidase method and plasma insulin concentrations were determined using a double antibody radioimmunoassay technique. Concentrations of selected amino acids were measured in sulfosalicylic acid extracts of whole blood using an automated ion-exchange chromatographic technique (D-500; Dionex Corp., Sunnyvale, CA). Leucine and phenylalanine specific activity were determined as previously described $(18,19)$.

Data analysis. All data are presented as means \pm SEM. Results from samples taken over the last hour of the basal and insulin (or saline) infusion periods were averaged for each subject. Statistical compari- sons between basal and insulin infused periods were performed using a paired $t$ test. A best fit curve relating phenylalanine and leucine balance to plasma insulin concentration was obtained using a nonlinear leastsquares method and a single hyperbolic function.

\section{Results}

Insulin, glucose, and amino acid concentrations. As shown in Table I local insulin infusion raised forearm deep vein insulin concentrations by $\sim 24,36,62$, and $118 \mu \mathrm{U} / \mathrm{ml}$ for the 0.01 , $0.02,0.035$, and $0.05 \mathrm{mU} / \mathrm{kg}$ per min insulin infusion rates, respectively. Forearm insulin concentrations were unchanged during saline infusion. Systemic insulin concentrations, obtained from the contralateral arm vein were not influenced by the local insulin infusion (Table I).

Arterial blood glucose concentrations showed a small but significant decline in most groups, including the saline controls. Arterial concentrations of phenylalanine and leucine were unchanged by local hyperinsulinemia (Table I), as were the concentrations of 11 other amino acids (not shown).

Forearm blood flow and glucose uptake. As shown in Table I, forearm blood flow was not significantly changed by the 0.01 , $0.02,0.035 \mathrm{mU} / \mathrm{kg}$ per min insulin infusion rates. At the highest dose, $0.05 \mathrm{mU} / \mathrm{kg}$ per min, a $25 \%$ increase in forearm blood flow was noted (10). Higher doses of systemically infused insulin have since been reported to produce even greater increases in leg muscle blood flow (20).

Glucose disposal, depicted in Fig. 1, showed a slight, 13\% fall in the saline infused group and a small, $18 \%$ increase in the $0.01 \mathrm{mU} / \mathrm{kg}$ per min insulin infusion group. The higher insulin infusion rates of $0.02,0.035$, and $0.05 \mathrm{mU} / \mathrm{kg}$ per $\mathrm{min}$

Table II. Forearm Amino Acid Kinetics

\begin{tabular}{|c|c|c|c|c|c|}
\hline & \multicolumn{5}{|c|}{ Insulin infusion rate (mU/kg per min) } \\
\hline & 0.00 & 0.01 & 0.02 & 0.035 & 0.05 \\
\hline & \multicolumn{5}{|c|}{ nmol/min per $100 \mathrm{ml}$} \\
\hline \multicolumn{6}{|l|}{ Phenylalanine } \\
\hline \multicolumn{6}{|c|}{ Net balance } \\
\hline Basal & $-19 \pm 3$ & $-16 \pm 3$ & $-12 \pm 5$ & $-14 \pm 4$ & $-14 \pm 4$ \\
\hline Infused & $-19 \pm 2$ & $-1 \pm 3^{*}$ & $1 \pm 1^{*}$ & $9 \pm 3^{*}$ & $9 \pm 3^{*}$ \\
\hline \multicolumn{6}{|l|}{$R_{\mathrm{a}}$} \\
\hline Basal & $55 \pm 7$ & $52 \pm 8$ & $42 \pm 5$ & $50 \pm 9$ & $57 \pm 5$ \\
\hline Infused & $52 \pm 5$ & $35 \pm 5^{*}$ & $31 \pm 2^{\ddagger}$ & $28 \pm 5^{*}$ & $33 \pm 5^{*}$ \\
\hline \multicolumn{6}{|l|}{$R_{\mathrm{d}}$} \\
\hline Basal & $37 \pm 5$ & $35 \pm 5$ & $30 \pm 3$ & $36 \pm 7$ & $43 \pm 5$ \\
\hline Infused & $33 \pm 3$ & $35 \pm 4$ & $33 \pm 2$ & $36 \pm 5$ & $42 \pm 2$ \\
\hline \multicolumn{6}{|l|}{ Leucine } \\
\hline \multicolumn{6}{|c|}{ Net balance } \\
\hline Basal & $-29 \pm 8$ & $-15 \pm 6$ & $-9 \pm 4$ & $-14 \pm 6$ & $-13 \pm 5$ \\
\hline Infused & $-18 \pm 5$ & $18 \pm 7^{*}$ & $38 \pm 7^{*}$ & $46 \pm 9 *$ & $61 \pm 8^{*}$ \\
\hline \multicolumn{6}{|l|}{$R_{\mathrm{a}}$} \\
\hline Basal & $139 \pm 22$ & $113 \pm 11$ & $96 \pm 8$ & $105 \pm 15$ & $126 \pm 9$ \\
\hline Infused & $121 \pm 13$ & $77 \pm 13^{\ddagger}$ & $57 \pm 10^{*}$ & $76 \pm 12^{\ddagger}$ & $63 \pm 9^{*}$ \\
\hline \multicolumn{6}{|l|}{$R_{\mathrm{d}}$} \\
\hline Basal & $111 \pm 16$ & $98 \pm 9$ & $87 \pm 7$ & $91 \pm 13$ & $113 \pm 12$ \\
\hline Infused & $103 \pm 13$ & $95 \pm 9$ & $95 \pm 6$ & $122 \pm 12^{\ddagger}$ & $124 \pm 12^{*}$ \\
\hline
\end{tabular}

${ }^{*} P<0.01$ basal vs. insulin; ${ }^{\ddagger} P<0.05$ basal vs. insulin. 

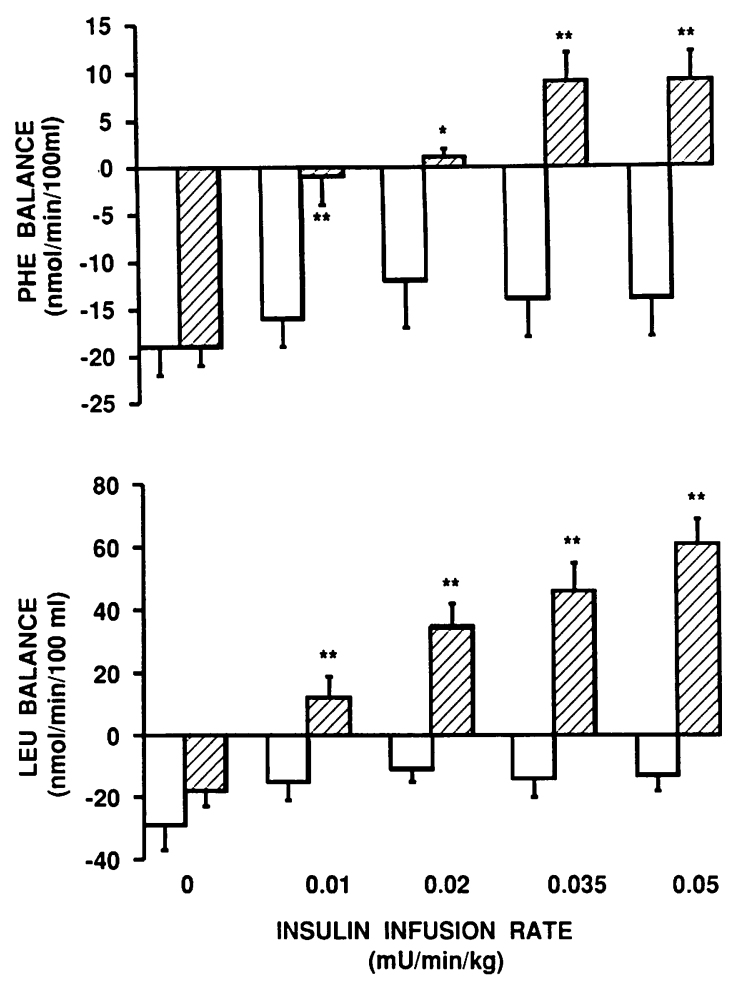

Figure 2. Effect of insulin on forearm skeletal muscle phenylalanine $(A)$ and leucine $(B)$ balance. Values are means \pm SEM during the last hour of the basal (open bars) and insulin-infused periods (hatched bars). ${ }^{*} P<0.05,{ }^{* *} P<0.01$ comparing basal and insulin-infused periods (paired $t$ test).

resulted in significant increases of glucose uptake of approximately twofold $(0.9 \pm 0.1$ to $1.8 \pm 0.3 \mu \mathrm{mol} / \mathrm{min}$ per $100 \mathrm{ml})$, threefold $(0.9 \pm 1$ to $2.4 \pm 0.4 \mu \mathrm{mol} / \mathrm{min}$ per $100 \mathrm{ml})$ and fourfold $(1.1 \pm 0.1$ to $4.7 \pm 0.7 \mu \mathrm{mol} / \mathrm{min}$ per $100 \mathrm{ml})$, respectively.

Forearm amino acid balance. The net balances for phenylalanine and leucine are shown in Table II and Fig. 2. During the basal period there was an ongoing release of phenylalanine and leucine. This persisted with saline infusion. Local insulin infusion caused a positive shift in forearm phenylalanine balance to values of $-1,1,9$, and $9 \mathrm{nmol} / \mathrm{min}$ per $100 \mathrm{ml}$ for the four insulin infusion doses, respectively. Local insulin infusion also produced a marked $(P<0.01)$ change in forearm leucine balance from a net release to a net uptake at all four insulin doses.

Forearm phenylalanine and leucine kinetics. The effect of local hyperinsulinemia on forearm skeletal muscle amino acid kinetics is depicted in Fig. 3 and Table II. During the saline infusion there was essentially no change in phenylalanine $R_{\mathrm{a}}$ and leucine $R_{\mathrm{a}}$. The $0.01 \mathrm{mU} / \mathrm{kg}$ per min insulin infusion produced a marked, $38 \%$ suppression of phenylalanine $R_{\mathrm{a}}$. Significant $26-44 \%$ suppression of phenylalanine $R_{\mathrm{a}}$ was noted in response to the higher insulin infusion rates. The effect of hyperinsulinemia on the rate of appearance of leucine mirrored that seen with phenylalanine: local hyperinsulinemia resulted in $24-48 \%$ suppression of leucine $R_{\mathrm{a}}$ across forearm skeletal muscle. As shown in Table III, the arterial concentrations and specific activities of both phenylalanine and leucine remained stable between the basal and insulin-infused periods, indicating that the amino acid tracers were at steady state throughout the study.
The effect of local insulin on the $R_{\mathrm{d}}$ of phenylalanine and leucine is shown in Table II. Phenylalanine $R_{\mathrm{d}}$, an index of protein synthesis, was unchanged in response to local hyperinsulinemia. The rate of disposal of leucine in muscle, which reflects not only incorporation into protein, but transamination and local oxidation as well, showed small, variable responses to hyperinsulinemia.

Fig. 4 depicts the dose-response relationships between insulin concentration and net forearm phenylalanine and leucine balance. The individual data points were constructed by plotting the mean amino acid balance during the last hour of insulin infusion for each subject against his/her mean deep vein insulin concentration during the same time period. The fitted curve is a nonlinear least-squares best fit to a hyperbolic function. Net forearm phenylalanine balance responded sharply to modest elevations of insulin concentration. The effect of insulin on phenylalanine balance was half maximal at an insulin concentration of $14 \mu \mathrm{U} / \mathrm{ml}$. The dose response curve for net forearm leucine balance was similar and the estimated halfmaximal effect of insulin occurred at a concentration of 13 $\mu \mathrm{U} / \mathrm{ml}$.

\section{Discussion}

The observations reported here suggest that net forearm balance of the essential amino acids phenylalanine and leucine is very sensitive to modest changes of plasma insulin. The lowest dose of insulin infused, which raised deep venous insulin concentrations by only $\sim 20 \mu \mathrm{U} / \mathrm{ml}$, produced a significant sup-
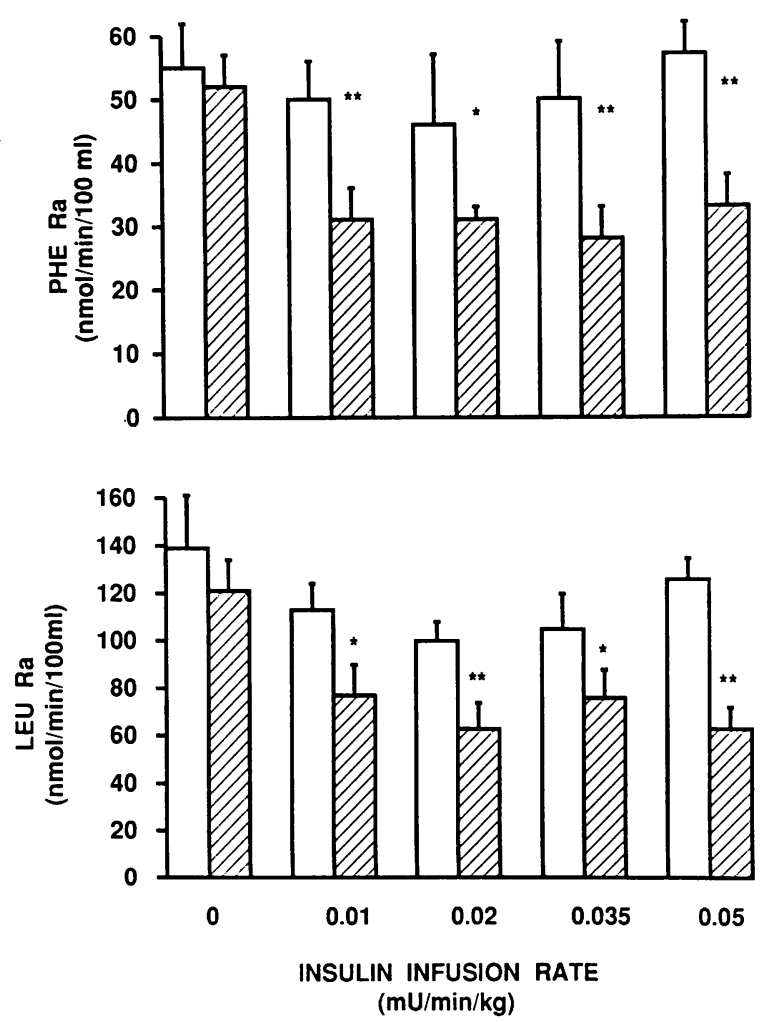

Figure 3. Effect of insulin on forearm skeletal muscle phenylalanine $(A)$ and leucine $R_{\mathrm{a}}(B)$. Values are means \pm SEM during the last hour of the basal (open bars) and insulin-infused (hatched bars) periods.

${ }^{*} P<0.05,{ }^{* *} P<0.01$ (paired $t$ test) comparing basal to insulin-infused period. 


\begin{tabular}{|c|c|c|c|c|c|}
\hline & \multicolumn{5}{|c|}{ Insulin infusion rate (mU/kg per $\mathrm{min}$ ) } \\
\hline & 0.00 & 0.01 & 0.02 & 0.035 & 0.05 \\
\hline \multicolumn{6}{|c|}{ Arterial phenylalanine $(\mathrm{nmol} / \mathrm{ml})$} \\
\hline Basal & $45 \pm 2$ & $42 \pm 2$ & $48 \pm 3$ & $44 \pm 2$ & $48 \pm 1$ \\
\hline Infused & $44 \pm 2$ & $40 \pm 2$ & $46 \pm 3$ & $44 \pm 2$ & $49 \pm 1$ \\
\hline \multicolumn{6}{|c|}{$\begin{array}{l}\text { Arterial phenylalanine specific } \\
\text { activity }(\mathrm{dpm} / \mathrm{nmol})\end{array}$} \\
\hline Basal & $33 \pm 1$ & $44 \pm 4$ & $31 \pm 4$ & $39 \pm 4$ & $20 \pm 2$ \\
\hline Infused & $35 \pm 2$ & $45 \pm 4$ & $32 \pm 3$ & $41 \pm 3$ & $22 \pm 2$ \\
\hline \multicolumn{6}{|c|}{ Venous phenylalanine $(\mathrm{nmol} / \mathrm{ml})$} \\
\hline Basal & $50 \pm 2$ & $45 \pm 2$ & $50 \pm 3$ & $47 \pm 3$ & $53 \pm 2$ \\
\hline Infused & $50 \pm 2$ & $40 \pm 2^{\ddagger}$ & $46 \pm 3^{*}$ & $42 \pm 2^{\ddagger}$ & $46 \pm 2^{*}$ \\
\hline \multicolumn{6}{|c|}{$\begin{array}{l}\text { Venous phenylalanine specific } \\
\text { activity }(\mathrm{dpm} / \mathrm{ml})\end{array}$} \\
\hline Basal & $22 \pm 1$ & $31 \pm 3$ & $24 \pm 2$ & $31 \pm 3$ & $13 \pm 1$ \\
\hline Infused & $24 \pm 1$ & $35 \pm 3^{*}$ & $26 \pm 3^{\ddagger}$ & $36 \pm 3^{*}$ & $18 \pm 2^{\ddagger}$ \\
\hline \multicolumn{6}{|c|}{ Arterial leucine $(\mathrm{nmol} / \mathrm{ml})$} \\
\hline Basal & $114 \pm 5$ & $116 \pm 8$ & $100 \pm 2$ & $105 \pm 7$ & $110 \pm 3$ \\
\hline Infused & $113 \pm 5$ & $112 \pm 6$ & $106 \pm 3^{*}$ & $105 \pm 7$ & $108 \pm 2$ \\
\hline \multicolumn{6}{|c|}{$\begin{array}{l}\text { Arterial leucine specific } \\
\text { activity }(\mathrm{dpm} / \mathrm{nmol})\end{array}$} \\
\hline Basal & $3.8 \pm 0.2$ & $3.6 \pm 0.4$ & $5.0 \pm 0.4$ & $4.4 \pm 0.4$ & $2.4 \pm 0.3$ \\
\hline Infused & $4.1 \pm 0.2$ & $3.7 \pm 0.4$ & $5.0 \pm 0.3$ & $4.7 \pm 0.4$ & $2.6 \pm 0.2$ \\
\hline \multicolumn{6}{|c|}{ Venous leucine $(\mathrm{nmol} / \mathrm{ml})$} \\
\hline Basal & $121 \pm 5$ & $119 \pm 7$ & $103 \pm 2$ & $108 \pm 8$ & $114 \pm 3$ \\
\hline Infused & $119 \pm 6$ & $107 \pm 5^{*}$ & $97 \pm 4^{*}$ & $97 \pm 7^{*}$ & $92 \pm 3^{\ddagger}$ \\
\hline \multicolumn{6}{|c|}{$\begin{array}{l}\text { Venous leucine specific } \\
\text { activity }(\mathrm{dpm} / \mathrm{nmol})\end{array}$} \\
\hline Basal & $2.5 \pm 0.2$ & $2.7 \pm 0.3$ & $3.7 \pm 0.3$ & $3.5 \pm 0.3$ & $1.5 \pm 0.2$ \\
\hline Infused & $2.8 \pm 0.2$ & $3.0 \pm 0.3^{\ddagger}$ & $4.1 \pm 0.1^{\ddagger}$ & $4.0 \pm 0.4^{\ddagger}$ & $2.1 \pm 0.2^{\ddagger}$ \\
\hline
\end{tabular}

${ }^{*} P<0.05$ basal vs. insulin-infused period. ${ }^{\ddagger} P<0.01$ basal vs. insulin-infused period.

pression of postabsorptive phenylalanine and leucine net release. Fivefold greater insulin infusion rates produced proportionately greater concentrations of forearm venous insulin, but did not effect a statistically significant further change in balance. For both amino acids inhibition of $R_{\mathrm{a}}$ accounted for the observed changes in net forearm amino acid balance, consistent with inhibition of muscle proteolysis. In studies of whole body protein turnover, using the continuous leucine infusion method, increasing plasma insulin by $11 \mu \mathrm{U} / \mathrm{ml}$ significantly diminished whole body leucine $R_{\mathrm{a}}$. The concentration of insulin required to half maximally suppress systemic leucine flux is reported to be $32 \mu \mathrm{U} / \mathrm{ml}(6)$. Bearing in mind that muscle protein is thought to account for only $\sim 25-50 \%(21,22)$ of estimated whole body protein turnover, differences in the observed dose response to insulin may indicate that protein turnover in nonmuscle tissues may be less sensitive to the small increments of insulin examined here.

The dose-response relationship observed in insulin action on forearm glucose uptake was markedly different. Unlike the amino acids, forearm net glucose balance increased progressively with increments of plasma insulin. In studies of whole body glucose disposal using the euglycemic insulin clamp technique, total body uptake of glucose, which predominantly reflects skeletal muscle $(23,24)$, is maximal at insulin concentra- tions in excess of $300 \mu \mathrm{U} / \mathrm{ml}$. The insulin concentration required for half-maximal stimulation has been estimated between 55 and $130 \mu \mathrm{U} / \mathrm{ml}$ by different investigators (3-5). In the current study, the observed progressive increases in skeletal muscle glucose uptake throughout the range of insulin concentrations examined in the current study is consistent with the suggestion that skeletal muscle glucose uptake is only saturated at insulin concentrations well above $100 \mu \mathrm{U} / \mathrm{ml}$.

Earlier studies of low or low and high dose forearm insulin infusions left unsettled whether insulin responsiveness of muscle protein and glucose metabolism differed (9). The current study demonstrates clearly that both the net forearm release and rate of new appearance of leucine and phenylalanine are markedly suppressed at insulin concentrations lower than those required to significantly enhance glucose uptake. Further, the maximal effect of insulin on muscle protein metabolism appears to be much lower than that required to maximally stimulate glucose uptake.

In studies of insulin action on total body protein turnover in humans, hypoaminoacidemia has been reported to blunt the antiproteolytic action of insulin (7). It is not currently known whether hypoaminoacidemia similarly influences proteolysis in muscle. In this regard, however, two laboratories have noted that during systemic insulin infusion (with accompanying hy- 

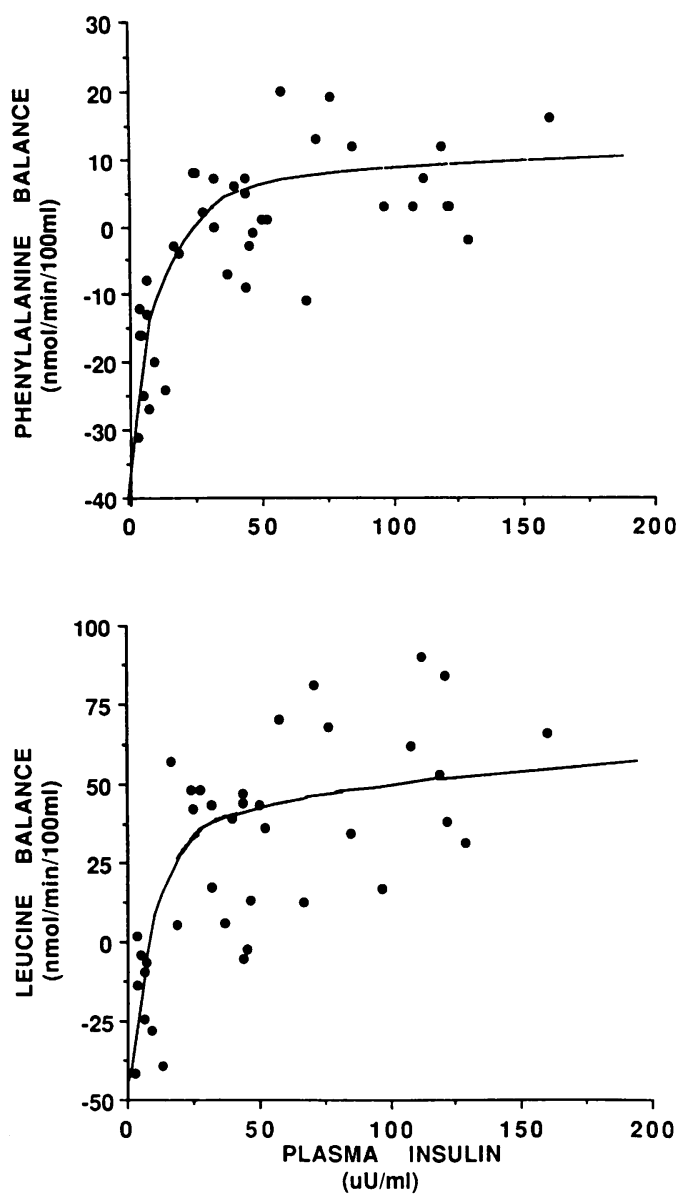

Figure 4. Dose-response relationship for plasma insulin concentration ( $x$ axis) and net forearm skeletal muscle amino acid balance ( $y$ axis). Individual data points were constructed by plotting the mean amino acid balance during the last hour of insulin or saline infusion against the subject's mean insulin concentrations during the same time period. Net forearm phenylalanine balance is shown in $A$ and net leucine balance in $B$

poaminoacidemia) phenylalanine $R_{\mathrm{a}}$ measured across skeletal muscle was not suppressed $(14,15)$. However, others (25) have observed that systemic insulin infusion, despite hypoaminoacidemia, suppressed skeletal muscle phenylalanine and/or leucine $R_{\mathrm{a}}$ from muscle. An explanation reconciling the different results during systemic insulin infusion is not currently available. However, the aggregate observations may serve to underscore the early cautioning by Zierler and Rabinowitz that balance measurements across the forearm are best made when the systemic arterial concentrations of substrates are at steady state (26).

There are wide areas of agreement between studies in which simultaneous infusions of insulin and amino acids were given. Regardless of the amino acid concentration, hyperinsulinemia within the physiologic range has fairly consistent effects on amino acid kinetics, producing a $22-60 \%$ suppression of proteolysis (6-8). Whole body protein synthetic rates seem more dependent on the concentration of plasma amino acids.

In a variety of in vitro preparations (e.g., hemicorpus [27], diaphragm [28], and isolated soleus or epitrochlaris muscle [29]) insulin stimulates muscle protein synthesis. While in many cases high concentrations of insulin were used, clear ef- fects are seen with physiologic insulin concentrations in some studies (30). As discussed previously by Stirewalt et al. (29) insulin's effects are most apparent in preventing the decline of muscle protein synthesis rates which otherwise occurs during prolonged tissue incubation. This circumstance might more closely mimic the in vivo setting of insulin replacement in insulin-deficient subjects, a circumstance not examined in the current study. However, measurements of insulin's effects on whole body leucine flux in poorly controlled type 1 diabetic patients again supports a dominant effect on tissue proteolysis (31-33).

Interestingly, the greater sensitivity of muscle to insulin's antiproteolytic action compared with glucose disposal might have indirect effects on body glucose metabolism. Like muscle amino acid release, hepatic glucose production is very sensitive to small increments of plasma insulin. Insulin infusions that increment systemic plasma insulin by $20 \mu \mathrm{U} / \mathrm{ml}$ suppress hepatic glucose production by $>50 \%$ while minimally increasing body glucose disposal ( 3 ). Inasmuch as circulating amino acids provide liver with substrate for glucose production by gluconeogenesis, suppression of proteolysis in muscle and at other sites might, by decreasing amino acid availability, indirectly limit hepatic glucose production. Assessment of this would require careful measurement of splanchnic amino acid balance during low dose insulin clamps.

A differential insulin sensitivity of amino acid and glucose metabolism was suggested over two decades ago by Cahill (1). Whether the exquisite sensitivity of muscle tissue to insulin's antiproteolytic action is altered in clinical states of insulin resistance is not known. We have recently observed that acute, experimental increases in circulating growth hormone to concentrations seen in acromegaly antagonizes the antiproteolytic action of insulin (34). We have previously reported that $60 \mathrm{~h}$ of fasting results in diminished insulin action on muscle glucose disposal but a fully preserved antiproteolytic action (19). It should prove informative to ascertain whether sensitivity to insulin's action on protein and glucose metabolism change in parallel or discordant fashion in pathologic states is associated with insulin resistance. The dose-response relationship defined in the current study should prove helpful in the design of such studies.

\section{References}

1. Cahill, G. F., Jr. 1971. Physiology of insulin in man. Diabetes. 20:785-799.

2. Fukagawa, N. K., K. L. Minaker, V. R. Young, and J. W. Rowe. 1986 Insulin dose-dependent reductions in plasma amino acids in man. Am. J. Physiol. 250:E13-E17.

3. Bonadonna, R. C., L. C. Groop, K. Zych, M. Shank, and R. A. DeFronzo. 1990. Dose-dependent effect of insulin on plasma free fatty acid turnover and oxidation in humans. Am. J. Physiol. 259:E736-E750.

4. Rizza, R. A., L. J. Mandarino, and J. E. Gerich. 1981. Dose-response characteristics for effects of insulin on production and utilization of glucose in man. Am. J. Physiol. 240:E630-639.

5. Kolterman, O., J. Insel, M. Saekow, and J. Olefsky. 1980. Mechanisms of insulin resistance in human obesity: evidence for receptor and postreceptor defects. J. Clin. Invest. 65:1272-1284.

6. Fukagawa, N. K., K. L. Minaker, J. W. Rowe, M. N. Goodman, D. W. Matthews, D. M. Bier, and V. R. Young. 1985. Insulin-mediated reduction of whole body protein breakdown. Dose-response effects on leucine metabolism in postabsorptive man. J. Clin. Invest. 76:2306-2311.

7. Flakoll, P. J., M. Kulaylat, M. Frexes-Steed, H. Hourani, L. L. Brown, J. O. Hill, and N. N. Abumrad. 1989. Amino acids augment insulin's suppression of whole body proteolysis. Am. J. Physiol. 257:E839-E847.

8. Castellino, P., L. Luzi, D. C. Simonson, M. Haymond, and R. A. DeFronzo. 1987. Effect of insulin and plasma amino acid concentrations on leucine metabolism in man. J. Clin. Invest. 80:1784-1793. 
9. Pozefsky, T., P. Felig, J. D. Tobin, J. S. Soeldner, and G. F. Cahill. 1976. Amino acid balance across tissues of the forearm in postabsorptive man. Effects of insulin at two dose levels. J. Clin. Invest. 48:2273-2282.

10. Gelfand, R. A., and E. J. Barrett. 1987. Effect of physiologic hyperinsulinemia on skeletal muscle protein synthesis and breakdown in man. J. Clin. Invest. 80:1-6.

11. Zeman, R. J., R. Ludeman, T. G. Easton, and J. D. Etlinger. 1988. Slow and fast alterations in skeletal muscle fibers caused by clenbuterol, a beta 2-receptor agonist. Am. J. Physiol. 254:E726-E732.

12. Andres, E., M. A. Baltzan, G. Cader, and K. L. Zierler. 1962. Effect of insulin on carbohydrate metabolism and potassium in the forearm of man. $J$. Clin. Invest. 41:108-115.

13. Andres, R., G. Caader, and K. L. Zierler. 1956. The quantitatively minor role of carbohydrate in oxidative metabolism by skeletal muscle in intact man in the basal state. Measurements of oxygen and glucose uptake and carbon dioxide and lactate production in the forearm. J. Clin. Invest. 35:671-682.

14. Tessari, P., S. Inchiostro, G. Biolo, E. Vincenti, and L. Sabadin. 1991. Effects of acute systemic hyperinsulinemia on forearm muscle proteolysis in healthy man. J. Clin. Invest. 88:27-33.

15. Arfvidsson, B., H. Zachrisson, A. C. Moller-Loswick, A. Hyltander, R. Sandstrom, and K. Lundholm. 1991. Effect of systemic hyperinsulinemia on amino acid flux across human legs in postabsorptive state. Am. J. Physiol. 260:E46-E52.

16. Barrett, E. J., J. H. Revkin, L. H. Young, B. L. Zaret, R. Jacob, and R. A Gelfand. 1987. An isotopic method for in vivo measurement of muscle protein synthesis and degradation. Biochem. J. 245:223-228.

17. Williams, I. H., P. H. Sugden, and H. E. Morgan. 1981. Use of aromatic amino acids as monitors of protein turnover. Am. J. Physiol. 249:E677-E691.

18. Louard, R. J., E. J. Barrett, and R. A. Gelfand. 1990. Effect of infused branched-chain amino acids on muscle and whole body amino acid metabolism in man. Clin. Sci. (Lond.). 79:457-466.

19. Fryburg, D. A., E. J. Barrett, R. J. Louard, and R. A. Gelfand. 1990. Effect of starvation on human muscle protein metabolism and its response to insulin. Am. J. Physiol. 259:E477-E482.

20. Laasko, M., S. V. Edelman, G. Brechtel, and A. D. Baron. 1990. Decreased effect of insulin to stimulate skeletal muscle blood flow in obese man. $J$. Clin. Invest. 85:1844-1852.

21. Gelfand, R. A., M. G. Glickman, P. Castellino, and R. A. DeFronzo. 1988. Measurement of L- $\left[1-{ }^{14} \mathrm{C}\right]$ leucine kinetics in splanchnic and leg tissues in humans: effect of amino acid infusion. Diabetes. 37:1365-1372.
22. Nair, K. S., D. Halliday, and R. C. Griggs. 1988. Leucine incorporation into mixed skeletal muscle protein in humans. Am. J. Physiol. 254:E208-E213.

23. Baron, A. D., G. Brechtel, P. Wallace, and S. V. Edelman. 1988. Rates and tissue sites of non-insulin- and insulin-mediated glucose uptake in humans. $\mathrm{Am}$. J. Physiol. 255:E769-E774.

24. Baron, A. D., O. G. Kolterman, J. Bell, L. J. Mandarino, and J. M. Olefsky. 1985. Rates of noninsulin-mediated glucose uptake are elevated in type II diabetic subjects. J. Clin. Invest. 76:1782-1788.

25. Denne, S. C., E. A. Liechty, Y. M. Liu, G. Brechtel, and A. D. Baron. 1991. Proteolysis in skeletal muscle and whole body in response to euglycemic hyperinsulinemia in normal adults. Am. J. Physiol. 261:E809-E814.

26. Zierler, K. L., and D. Rabinowitz. 1962. Effect of very small concentrations of insulin in forearm metabolism. Persistence of its action in potassium and free fatty acids without its effects on glucose. J. Clin. Invest. 43:950-962.

27. Jefferson, L. S. 1980. Role of insulin in the regulation of protein synthesis. Diabetes. 29:487-496.

28. Fulks, R. M., J. B. Li, and A. L. Goldberg. 1975. Effects of insulin, glucose, and amino acids on protein turnover in rat diaphragm. J. Biol. Chem. 250:290298.

29. Stirewalt, W. S., R. B. Low, and J. M. Slaiby. 1985. Insulin sensitivity and responsiveness of epitrochlearis and soleus muscles from fed and starved rats. Biochem. J. 227:355-362.

30. Frayn, K. N., and P. F. Maycock. 1979. Regulation of protein metabolism by a physiological concentration of insulin in mouse soleus and extensor diigitorum longus muscles. Biochem. J. 1984:323-330.

31. Nair, K. S., J. S. Garrow, C. Ford, R. F. Mahler, and D. Halliday. 1983. Effect of poor diabetic control and obesity on whole body protein metabolism in man. Diabetologia. 25:400-403.

32. Robert, J. J., B. Beaufrere, J. Koziet, J. F. Desjeux, D. M. Bier, V. R. Young, and H. Lestradet. 1985. Whole body de novo amino acid synthesis in type I (insulin-dependent) diabetes studied with stable isotope labeled leucine, alanine and glycine. Diabetes. 34:67-73.

33. Umpleby, A. M., M. A. Boroujerdi, P. M. Brown, E. R. Carson, and P. H. Sonksen. 1986. The effect of metabolic control on leucine metabolism in type I (insulin-dependent) diabetic patients. Diabetologia. 29:131-141.

34. Fryburg, D. A., R. J. Louard, K. E. Gerow, R. A. Gelfand, and E. J. Barrett. 1992. Growth hormone stimulates skeletal muscle protein synthesis and blunts insulin's antiproteolytic action in humans. Diabetes. 41:424-429. 